\title{
From Socio-politics to Kinship Dynamics Among the Kaingang
}

Cinthia Creatini da Rocha / Doutoranda PPGAS-UFSC

\section{Resumo}

O artigo centra-se em dados etnográficos da organização social e política de um coletivo Kaingang que atualmente reivindica a identificação da Terra Indígena Sêgu (Rio Grande do Sul). Tomando como foco a centralidade da sócio-política indígena busca-se compreender algumas situações em que as alianças ou cisões entre parentes e afins são postas em cheque. Os dados etnográficos observados em diferentes terras indígenas Kaingang localizadas na porção sul do país apontam para a existência de uma intrincada e rizomática rede de relações sociais intra e inter-grupos, famílias e pessoas que, para além de suas localidades de origem ou locais de moradia, articulam princípios sócio-cosmo-políticos que marcam os distintos processos de alianças e rupturas, reciprocidades e cisões. Nesse sentido, o parentesco deve ser analisado como um processo contextual, no qual suas dinâmicas devem ser analisadas caso a caso.

Palavras-chaves: parentesco; sócio-política; Kaingang; poder

\author{
Abstract \\ This article is based on ethnographic data on the social and political \\ organization of a Kaingang collective that is currently requesting the \\ demarcation of the Terra Indígena Sêgu [Sêgu Indigenous Land] (in Rio \\ Grande do Sul State in southern Brazil). Ethnographic data observed in \\ various indigenous Kaingang lands in southern Brazil point to an intricate \\ and rhizomatic network of social relations within and between groups and \\ families, which, beyond their locations of origin or residence, articulate \\ socio-cosmic-political principles that mark distinct processes of reciprocities \\ and divisions. Here, the movement for land claims and internal tensions \\ within the collectives either result in distancings or approximations that \\ are translated into principles of inclusion or exclusion of individuals and \\ groups in relation to territories that are already occupied and or being
}


claimed. Thus, if for non-Kaingang the Kaingang- as for other Amerindian populations - project an ethnic identity based on the idea of a generalized kinship, at the level of their intra- and inter-group relations, the fluidity with which the ties among those who are considered relatives (kanhkó) or not, can be easily made or unmade, strengthened or broken.

Keywords: sociopolitical; kinship; Kaingang; indigenous lands 


\section{From Socio-politics to Kinship Dynamics Among the Kaingang'}

Cinthia Creatini da Rocha / Doutoranda PPGAS-UFSC

This article is based on ethnographic data gathered among a Kaingang collective that has made claim to the Sêgu Indigenous Land in Rio Grande do Sul State in southern Brazil, ${ }^{2}$ located in the municipalities of Constantina and Novo Xingu in the north of the state. Through close interaction with these indigenous people during the studies conducted by a Technical Group ${ }^{3}$ established by FUNAI, an attempt was made to trace a parallel between questions of kinship and those about local sociopolitical and territorial relations.

With more than 33 thousand people, the Kaingang are currently distributed over more than 40 indigenous lands (legalized or in the process of legalization) located in São Paulo, Paraná, Santa Catarina and Rio Grande do Sul States (FUNASA, 2009 and FUNAI, 2009). There are also families that live outside the indigenous lands, on the periphery of urban centers or in rural regions of these states and for which no precise data is available (ISA, 2010). The numbers are substantial: the Kaingang alone correspond to nearly $50 \%$ of the entire population of peoples of the Jê language, being one of the five most populous indigenous peoples in Brazil (Portal Kaingang).

The sociopolitical context observed among the Kaingang who are asking for demarcation of the Sêgu lands expresses situations similar to those that

1 A first version of this article was presented at the 27th Brazilian Anthropology Meeting at the Working Group "Kinship, political processes and domestic ecology: ethnography of indigenous peoples in colonial, neocolonial and post-colonial contexts (August 1-4, 2010 in Belém, PA) under the title "O parentesco como mote de reflexão acerca dos processos de alianças e cisões Kaingang" [Kinship as a theme for reflection about the processes of alliances and divisions among the Kaingang]. I would like to thank the suggestions and comments from the coordinators of the work group, Fábio Mura and Andrey Cordeiro Ferreira. The text can be found at: http://www.iconecv.com.br/27rba/arquivos/grupos_trabalho/gtog/ccr.pdf.

2 Read Xengu.

3 Projeto 914BRA4008 - FUNAI/UNESCO. Portarias FUNAI: no 475 [DOU 12/05/2009]; no 686 [DOU 03/07/2009]; no 150 [DOU 05/02/2010]; nº 1.159 [DOU 20/08/2010]. The author was anthropologistcoordinator of the Technical Group. 
also occur in other places occupied by these indigenous collectives. In general, the existence of an intricate and rhizomatic network of social relations is identified between and within groups and families. which beyond their locations of origins or residence, articulate socio-cosmic and political principles in distinct processes of reciprocities and divisions. Thus, the indigenous lands that belong to the Kaingang in southern Brazil - between Paraná and Rio Grande do Sul States ${ }^{4}$ - are characterized by this large web of relations that absorb each location, shaping a broader panorama of socio-political arrangements.

In recent decades, the Kaingang have conducted various articulations and movements for the demarcation and expansion of their territorial domains as recognized by the laws governing indigenous peoples and their rights (The Brazilian Constitution/ 1988; Decree 1.775/1996; Regulation 14/1996). Since the 1970s, these activities have resulted in the proliferation of Indigenous Assemblies. Indigenous communities from southern Brazil have established ties with leaders from other communities and non-governmental entities that support the indigenous cause In 1978 they held the first large Kaingang demonstration for the return of portions of the Nonoai Indigenous Land, which had been occupied by about three thousand small farm families. In the 1980s, the articulation between the Kaingang with certain NGOs became more firmly established and the rights of the original populations were determined, based on the Federal Constitution of 1988. This political situation stimulated the Kaingang in various locations to organize as an indigenous people to demand their rights and the demarcation of their lands in a more decisive manner. Between 1990 and 2000, the collective articulation of the Kaingang lost part of its strength and the groups dispersed, as isolated work fronts were formed that sought isolated territorial demands. At this time, the weakening of the collective mobilization generated a series of criticisms of the indigenous movements and of the sociopolitical organization of the Kaingang. Nevertheless, it is now possible to see that the change in posture of the indigenous peoples appears to have been precisely the spark for the results achieved in the first decade of the new century, when a series of demands for the identification, expansion and demarcation of their lands

4 The Kaingang also inhabit some indigenous lands in São Paulo, although the author does not have sufficient ethnographic data to insert this region as an element for comparison. 
began to be recognised by FUNAI.

Currently, the Kaingang political movement has been characterized by a concern, expressed mainly by the older leaders, for the need to rearticulate the indigenous collectives from different areas - as had been the case in the 1970 and 1980 - to build a common discourse aimed at non-indigenous people and the state. In their declarations, the elders emphasized the existence of an ethnic Kaingang identity that was sustained under the banner of kinship, or the notion that all the members of the people are considered to be each other's relatives. This discursive rhetoric - frequent also among many other indigenous people of the low lands - even if it is a political tool used by the Indians, does not fail to call attention to a network of relations that extend, in the case of the Kaingang, beyond the physical limits of the indigenous lands. But, if all the Kaingaing, are - at least in the passionate discourse to the outside world - considered in some way related to each other - through ethnic identity - what in native terms causes some of them to be considered more related than others? And what native terms are these, given that, according to Viveiros de Castro (2002), their kinship is probably not the same kinship as ours.

"The decision to give the same name to two concepts or different multiplicities is not justified, then, because of their similarities, and despite their differences, but to the contrary: the homonymy seeks to emphasize the differences, despite the similarities. The intention, precisely, is to make kinship want to say something else" (Viveiros de Castro, 2002: 407, emphasis by the author).

If for outsiders, in conflicts with society involving the State, it is advantageous to display cohesion under the banner of kinship, behind the scenes of indigenous life, tensions can either result in distancings from, or approximations to particular groups and/or individuals. Here, what is worth noting is that these contexts of internal socio-political disputes are directly associated to the principles of the inclusion or exclusion of individuals to groups or of groups to territories that are already occupied and or being claimed. Thus, if on one side, a collective identity is constructed based on kinship that represents, or better, presents the Kaingang to the surrounding society as a cohesive "people," on the other, what is striking at the level of inter- and intra-group interaction is the fluidity with which the ties between those 
who are considered kinsfolk ( $k a n h k o^{5}$ ) or not, can be easily made or unmade, strengthened or broken.

The literature on the Kaingang emphasizes the dualism present in the exchanges between exogamous moities, a characteristic of other Jê-speaking indigenous peoples considered fundamental to their social and political organization, (Veiga, 1996; Fernandes, 2003; Almeida, 2003; Crepèau, 1997 and 2002). Even if today, in different ethnographic contexts, the centrality of this dualist matrix is no longer focussed on the moities kamé and kairu, it is impossible to deny the presence of other dualist socio-cosmological principles that prescribe indigenous sociability. In the past, there may have been excessive concern among anthropologists to seek socio-cultural rules and standards that characterize the Kaingang in order to place them in dialog with the other Jê-Bororo peoples - who were studied extensively during the Harvard Brazil Central project. Today, an alternative ethnographic perspective concentrates much more on the complexity of indigenous life, recognizing its potential for transformation and the native responses to the presence of alterity, more than a need to apply rigid theoretical models that must be followed.

From the records of 19th century observers, we know that the Kaingang were distributed in numerous large groups. Engineer Pierre Mabilde (1983 [1836-1866]) indicated that these groups were established in political configurations of inter-connected families. These groups were formed around a male figure who acted as "the head" of the group. According to the analysis of the hirstorical documents undertaken by Ricardo Cid Fernandes, the interlinking of these indigenous families "expands and contracts to form the units that we call local groups and political-territorial units" (Fernandes, 2003a: 119). This author affirms that the articulation among family groups, domestic groups and parentagens ${ }^{6}$ allows defining the model of sociability

5 While the term kanhkó can be translated as "relative," it does not refer to "relatives" who encompass the local and global dimensions of the identity or ethnic constructions. As Gibran explains in his masters dissertation that will be defended at PPGAS/ UFSC in 2012, kanhkó points more specifically to the construction of networks of effective relationships, which are not necessarily limited to the context of the village. This is a category, therefore, that is directly related to the deliberate use of the identification of consanguines, or even of the approximation of affines through principles that are fundamental to the process of Kaingang kinship.

6 A native category that is part of the Kaingang language, but which is separated from the principles of descent and residence. Defined by the relationship that some individuals maintain with certain domestic groups, parentagem expands the relations contained in the domain of the domestic group through acts of mutual assistance. The individuals who are part of it come together for certain purposes, on certain 
that is at the basis of the configuration of the Kaingang communities in the current context (idem, p.87).

In the case of Rio Grande do Sul, the request by two extended Kaingang families for the identification of the Sêgu Indigenous Land (in the municipalities of Constantina and Novo Xingu) mirrors what has taken place in other contexts that involve indigenous peoples in southern Brazil. A constant movement of comings and goings of indigenous families throughout the territory, whether between those areas that have already been recognized, or in municipalities in the state that were established over former indigenous settlements and that are now claimed as Kaingang lands may be considered traditional. This spatial mobility ${ }^{7}$ marks an intrinsic characteristic of the Kaingang occupation of Brazil's southern plateau region since historic times, when groups of interconnected families were present throughout the araucaria forests in the regions of the grasslands and along river banks. ${ }^{8}$

Thus, similarly to this past when small groups of Kaingang families were separated by large distances, but maintained a certain communication between their settlements along trails, the sociopolitical networks that mobilize the indigenous people today extend beyond defined geographic limits. Among the collectives of distinct indigenous lands, the networks, connections and flows are established as a result of marriages, alliances or political disputes, illness and visits to relatives, the realization of public events and festivals and seasonal movements for selling crafts. Like their ancestors, entire families move from one region to another in a short period of time, reproducing a model of circulation along the extension of traditionally occupied lands that grouped distant kinship networks. These population expansions stemming from sociopolitical and historic processes had repercussions in geopolitical expansions, which frequently were translated into many of

occasions, in which participation is always optional (Fernandes, 2003).

7 Kaingang spatial mobility is a practice that is highly questioned by non-indigenous people healthcare, educational professionals, those from FUNAI and government - who deal directly with indigenous issues and manifest a certain difficulty in understanding the frequent shifts of the indigenous families among lands.

8 In the 18th century, the historian Lozano reported that the Gualacho and Guaianá lived from hunting and fishing and did not remain more than two years in the same place. The economy was based on collecting pine nuts (araucária pine seeds), from which they made provisions, and the products of hunting. The Kaingang food regime was complemented by honey, wild fruits, and the varieties of squash and corn they planted. 
the land claims for new identifications or for reviews of the boundaries of the already occupied areas. The confinement imposed on the Kaingang who were encircled within the territorial limits of the settlements - which were later transformed into indigenous lands - has led to difficulties and restrictions to their traditional way of life. It would appear that the networks of relationships between the different collectives that inhabit the current indigenous lands continue to steer the socio-spatial and political organization of the Kaingang. It is in the context of the operationality of this principle, that the claim to the Sêgu Inidigenous Land comes into being.

\section{The Case of the Sêgu Indigenous Land - connections among political and kinship processes}

The demand for identification of the Sêgu Indigenous Land is the result of the articulation of two extended families - who are not "aparentadas" or related to each other ${ }^{9}$ - who affirm that they originally came from the region. In conjunction with them, at the core of the political actions for this claim, other groups who live in other indigenous areas have joined them. Their political leaders, guide and counsel those who are directly making the land claim. During the period of our stay with these indigenous leaders, more than once we witnessed meetings with political leaders from the Indigenous Lands of Iraí, Rio dos Índios and Serrinha (all located in RS) and in which the main issue was the claim for the Sêgu lands. Even if the indigenous discourse emphasized that due to the kinship ties the Kaingang lands are directly linked to the presence and trajectory of certain groups of families, who have precedence over others, this is not to say that the retaking of the territories is perceived as conquests by one or another group but of the Kaingang "people," who once again come to incorporate their historic territorial patrimony, part of those lands that had been expropriated. In this way, the current claims for Kaingang lands can only be employed by those groups who can claim descent from ancestors who inhabited a certain region. Nevertheless,

9 The use of the term "parente" or relative can be extended not only to those criteria linked to processes of consanguinity and proximity, but also to a broad and contextually extensive identity that encompasses either the "relatives" who live in the same village, or all those who say they belong to a single ethnic group, or to all those recognized as indigenous, the appeals that use native classifications about those who are or are not "related" cannot be ignored. 
upon being demarcated, these regions may- at least in theory - receive families and descendants from other locations who may want to come live in that place. In these situations, it is the cacique (chief) in conjunction with other local leaders who decides whether or not to accept domestic groups from other locations.

The two extended famnilies who are at the core of the political actions for the demand for the Sêgu Indigenous Land, are based on two couples: Vivaldino and Matilde on the one hand; Martina and Lorenço on the other. However, only Vivaldino and Martina ${ }^{10}$ are considered to belong to the "old trunk" (tronco velho) ${ }^{11}$ of the location, the first because he was born in the region and the second because she is a direct descendent of an indigenous family from there (her materal grandparents and her mother were born and lived in that region until they were expelled by colonizers). In theory, each one of the old couples gather around them their unmarried sons and daughters, sons in law, grandchildren and other dependents, thus constituting a domestic group $^{12}$ that is based on the principle of uxorilocality (Veiga, 1998; Fernandes, 2003). I say "in theory" because we now increasingly observe that uxorilocality is no longer a general rule, and there can be an inversion of the residential standards according to the socio-political-economic interests of all new couples and of the family that takes them in. This sociopolitical rearrangement has a similar justification among the Kaingang as that which Fausto observed among the Tupinambá groups that lived along the Brazilian coast:

"a residential unit depends on the ability of a man to attract the largest possible number of son-in-laws, and at the same time, retain some of his male children. In other words, someone who can enforce the uxorilocal "rule" for his daughters, and can avoid it for this sons (and for himself)" (Fausto, 1992: 389, emphasis by the author).

This strategy means that in a an indigenous area one among these family heads stands out from the others to become recognized as the overall leader,

10 Both were central to the representation of the land claim movement before FUNAI, sustaining part of the construction of the report based on their memories that allowed bringing to light the history of the indigenous groups that had lived in the region.

11 The native category tronco velho (old trunk) refers to a certain territory and highlights the life trajectory of a person connected to the past, present and future.

12 Ceremonial, social, educational economic and political responsibilities lie within domestic groups. 
the cacique. Thus, a Kaingang cacique is he who attracts a number of domestic groups to join his own extended family. By avoiding the rule of uxorilocality and keeping his male children close, he is also able to attract the families of his daughters-in-law, who will ally thesmelves to him in gratitude for the care he has taken of their daughters.

From the time the Technical Group began its work we observed a latent dispute between the men of the two principal groups. Even if disputes for the control of political power were common among groups that lived on the same Kaingang land and were related to what was called "factionalism" by some historic reports, it should be noted that in the case of the Sêgu, the flames of animosity were fanned after the decree that created the Technical Group. In this context of such power disputes, it should be emphasized that the political efficacy of some groups is directly linked to their capacity to articulate networks of social relations that encompass indigenous and non-indigenous people (both living and dead) and also non-humans. In the context in question, during the movement for the Sêgu land claims, the main strategies used by each one of the principal domestic groups involved the search for allied families who lived on other indigenous lands, as well as articulation with people linked to NGOs (such as COMIN), the Federal Public Ministry in Passo Fundo and the municipal government of Constantina or even the emphasis on the kinship ties established with dead relatives who had lived in the region.

The two domestic groups that are at the center of this arena of political dispute come from different indigenous lands where they were subordinate to local leaders. In most cases, those who are not close to the leading domestic group are deprived of the symbolic and material goods that circulate in the villages and that are distributed by the cacique and the other leaders to their supporters. These situations generate dissatisfaction among the "excluded" families who come to question the exercise of power. Meanwhile the leaders, when they feel that the positions they occupy are being threatened, can take authoritarian measures and transfer to another indigenous area those families who cause them discomfort or, under socio-political pressures, the discontented families themselves can look for another place to live far from persecution, punishment and exclusion. In these circumstances, those who are not satisfied have two options, either they try to establish links to the cacique of another indigenous land, or they seek their own geopolitical 
expansion through a land claim to another area that is part of the old traditional land of Kaingang use and occupation.

The claim to the Sêgu Land began in about 2003. The families concerned organized various temporary encampments within the land they were seeking, but suffered continual pressure from non-indigenous residents and public agencies such as the municipal governments of Constantina and Novo Xingu who did not accept the presence of the Kaingang in the region. Thus, at various times, the indigenous families were expelled from the locations where they were camped and had to seek shelter in the houses of relatives who were in areas already regularized, as is the case of the Serrinha Indigenous Land, which is close to the land being claimed. After a few tense situations, FUNAI placed the Kaingang of Sêgu in an unoccupied building in the Serrinha Indigenous Land and began anthropological studies on which they could base their demands.

Prior to the installation of the Technical Group, there had been no internal dispute. Nevertheless, over time, the lodging at Serrinha brought to light a series of factors that were aggravating the relationship between the two domestic groups involved in the movement. Within the structure of the dwelling, separate spaces were marked with pieces of tarpaulin to identify the rooms occupied by the nuclear families. This spatial configuration goes against the Kaingang ideal that involves the formation of a core group, the proximity of members of a single extended family and the separation or distancing between domestic groups of distinct origins. In addition, the precariousness of the sanitary conditions, the restricted access to almost inexistant sources of income and the lack of opportunity to collect materials to produce crafts and or conduct any other subsistence activity (planting, providing services, etc.) as well as the political subordination to the leaders of Serrinha, created new tensions. In part, this explains why since 2008 a series of documents prepared by these families have been registered - from one group and another - and presented to the Federal Public Ministry at Passo Fundo (RS), ${ }^{13}$ indicating the internal division and dispute for leadership of the movement.

At the beginning of 2009, the tense climate that dragged on between

13 It is interesting to note that the Kaingang recognize the Federal Public Ministry as an allied outside institution that is able to provide them legitimacy in their actions, whether through the land claim, or through the manifestation and expression of internal socio-political principles. 
the two groups led to their definitive separation. It appears that what triggered the split in 2008 was the marriage between the oldest son of Lorenzo and Martina with one of Vivaldino's granddaughters. Until that time, the young man was considered one of the main political leaders of his group and of the indigenous movement as a whole. Nevertheless, upon marrying a girl who belonged to the opposing domestic group, he began to enter into disagreement with his parents and brothers. For a certain time, the people of his family nucleus insisted that the young man break off the relationship with the girl, but he did not accept the suggestion and went to live with her family who also sought his representation in the claims. Threatened by the decision of the son who left them, thus strengthening the opposing domestic group, the boy's parents -Lorenzo and Martina - decided to leave the lodging in the structure in the Serrinha Indigenous Land and went to live on a small site located within the land that was being claimed (in the municipality of Constantina) and that they had purchased with their own financial resources. They were joined by 13 other nuclear families- including unmarried sons, a daughter with her husband and other people who fit into the category of parentagem. At the Serrinha Indigenous Lands, 22 nuclear families remained - including the grandchildren, sons-in-law and other dependents who were linked to Vivaldino's group.

Since then, the movement for the identification of the Sêgu Indigenous Land has been divided into two distinct socio-spatial and political units. On the side of Martina and Lorenzo, Lorenzo and his second-oldest son assumed the titles of cacique and vice of the movement, with the support of those families who went with them to the small area located within the indigenous lands being claimed. On Vivaldino's side, Lorenzo and Martina's oldest son became the representative of the group, since he was now married with their granddaughter. What is interesting about these events is that an arrangement which could have led to greater solidarity - the fruit of a marriage and therefore alliance between members of the two main domestic groups involved with the land claim- became the opposite, at least from the point of view of one of the sides. In this case, the marriage of the couple's oldest son became a festering wound for Martina, Lorenzo, and their single sons, daughter and son-in-lw who continued to live together in the same residence. The young man's attitude was considered to be a blow that weakened them politically and strengthened the rival group - given that the leadership role that the boy 
had until that moment would now add to the power of their affines.

To justify what happened, there were no lack of accusations from the parents of the boy in relation to the group of men related to Vivaldino's "trunk" - both the girl's brothers, as well as those married to her maternal aunts - affirming that they had "plotted" the youth's romantic relationship with the girl, and later insisted that he assume the commitment and take her as his wife. In turn, declarations of Vivaldino's group emphasized that the only ones displeased with the marriage were the parents of the groom, because on the bride's side they were all content. While the boy's parents were upset with the loss of symbolic-political capital - stemming from his network of political articulations - that the boy took with him, certainly the affines who received him were aware that the "payment" made by the youth for marrying the girl would include these gains.

This is in fact what happened, since after the marriage the recently-married youth came to assume the political representation of his wife's group, assisted by other men in that group. But, while the young man's specific knowledge gave him a distinct status in issues related to the land claim or the search for other goods and services that were a primary need of the indigenous families (healthcare services, education, food supplies, etc), the same could not be said of the place that he occupied in the relations that he established with his group of in-lws within the encampment where he came to live. His condition was clearly one of fragility in relation to the demands of the other men who expected that he would present "practical" results, that is, the "benefits," of his ability for articulating political support from the outside world.

By paying attention to this context, trying to understand the displeasure of the parents and other members of the nuclear family of the married youth on one hand and the demands made by his in-laws and other influential men in the domestic group of his wife on the other, we can conclude that: the "legitimate" relatives (kanhkó) - in which are included both the consanguines as well as the real affines who were brought together because of their co-residential situation (not necessarily in the same house, but in the same space) - exist to help, and mark their relations of commensality, reciprocity and solidarity. The men belonging to a single residential nucleus mutually help each other in issues that involve politics and the realization of manual labor. Meanwhile, the women mainly share care for the home and children. And 
they all share the earnings - and obviously the necessary tasks - that are related to the economic production of the group, whether they concern the production and sale of crafts such as baskets, or the obtaining of any other money received from pensions ${ }^{14}$ or services provided to third parties. Therefore, the support among relatives is an ethical rule of conduct of the Kaingang and, when taken to its most farthest extreme, also ends up taking on, as we have tried to show, a potential political solidarity.

In June 2009, when the Technical Group was in the field to continue the identification studies for the Sêgu Indigenous Land (the first trip was in May 2009), there was no longer any dialog between the indigenous families linked to one or the other group. To reduce the combative atmosphere, a number of meetings were mediated by Kaingang leaders from other indigenous lands who either supported one group or the other, according to the interests that were at stake. At that time, what was at the heart of the trouble between the two domestic groups was the dispute over political leadership, given that Martina and Lorenzo affirmed that Lorenzo was the cacique of the Sêgu even before the indigenous land was truly guaranteed. The Technical Group displayed impartiality indicating that it recognized the two groups as central to the articulation of the claim. This could appear to be a problem, if one idealized a cohesive indigenous movement as necessary antecedent for a successful land claim. Yet it became an important element to affirm the particular socio-political organization of the Kaingang. The factionalism described for the past is found to be present to this day and indicative of the need for the Sêgu Indigenous Land to be sufficiently large to be able to guarantee the co-existence and co-presence of the two distinct domestic groups.

After a few months, Vivaldino's group that had remained in the building at the Serrinha Indigenous Land began to feel at a disadvantage for living outside the area under claim. Strategically, Lorenzo's group began to articulate with sectors of the Constantina municipal government, requesting a school for the children and healthcare for the indigenous families who were under their responsibility. He continued to assert himself as the cacique of Sêgu and his oldest son as the vice, which meant that little by little they were

14 Martina, a retired indigenous teacher, commented on more than one occasion that her pension since the beginning of the movement was divided among all those involved with the movement, whether to feed the families or to meet those expenses needed to maintain the movement, such as payment of bus tickets or fuel for the transportation of leaders to FUNAI in Passo Fundo. 
recognized as representatives of the indigenous movement by the Kaingang who lived in other areas and even by the non-indigenous people in the region. Lorenzo and Martina's oldest son continues to live with his affines, and was considered the leader of this group. According to the boy's father, the distance from his son was no longer a problem created by the others who had set a "trap," but that he "caught" the woman of the rival group as a consequence of his own acts. Between the young man and his brother, who now occupied the leadership position that he had left, there was a climate of ill-will and mutual accusations whenever they met or whenever when they made any comment about each other. ${ }^{15}$

At the end of 2009, the indigenous families in the Serrinha Indigenous Land decided to leave and set up an encampment close to where Lorenzo and Martina's group was located. This reignited the disagreement between the members of both groups. The following months were marked by various meetings during which leaders from other Kaingang lands, the COMIM and the Federal Public Ministry tried to bring the two sides together, so that they could constitute a single leadership to present the Sêgu land claim. Shortly before the Technical Group returned for the last phase of field work, the Kaingang from both sides met and signed an agreement naming the leaders who would represent them in the land claim process. Thus, ceding to pressures from Lorenzo's group, and from leaders of the other areas who were supporting him, the men from Vivaldino's side agreed to recognize the leadership of Lorenzo and his son who had already been presenting himself as the vice. Nevertheless, they required that one of Vivaldino's son-in-laws should be a leader of the movement, as the representative of the interests of the families belonging to that particular group. Here was one more interesting rearrangement. Lorenzo and Martina's oldest son, who had always stood out for his capacity for political articulation with the outside world, was excluded from the internal agreements and negotiations. What was not clear to me in this context, since the work of the Technical Group's had been concluded and it was not possible to continue the ethnography, was if the exclusion of Lorenzo's oldest son - the focus of the original rupture - had been

15 In more than one ethnographic context in which the rule of the uxorilocality was evaded, I noted that there was an intrinsic dispute between oldest sons to substitute or divide with the father the attributes related to political power of the residential nucleus or even of the village/indigenous land when the family in question stands out from the others because of its leadership status. 
influenced by his family of origin (mainly his father and brother) given that they no longer saw him as a "legitimate" kanhkó, but now as a possible threat; or if it had been brought about by the group of affines - now his "legitimate" kanhkó - who feared that the young man, by once again taking leadership in the indigenous movement, could return to "align or unite" with his family of origin, and strengthen them once again.

\section{Final Considerations}

If I understand the ideas of Viveiros de Castro, which are based on his study of kinship among indigenous Amazon groups, I would like to try to advance his interpretation about affinity as a given in the cosmic relational matrix and consanguineity as a province of the constructed world (2002: 406), to illuminate the description presented above about the dynamics of politics and kinship among the Kaingang. According to the author, what is interesting to understand "is not so much who is a consanguine or an affine, which differs from one relational world to another - the Amerindian and the Western - but, in the first place and above all, what is a consanguine and an affine" (idem, ibidem, emphasis in the original). In this sense, it seems obvious to note, based on what I have described, that among the Kaingang, it is much more interesting to join a group of affines, than to remain with the members of one's family of origin. But this is not at all new to Amerindian ethnology, given that what it is important to ask is what makes some people more legitimate relatives than others. And here one reaches the point of responding to the question raised at the beginning of this article: what is observed for the Kaingang does not seem to differ much from the idea proposed by Viveiros de Castro (2002) for the Amazonian Amerindian worlds, where the process of including or excluding those who are considered relatives is not based on blood ties or on the alliance established between people, but on factors that are directly related to the indigenous sociopolitical dynamic. Certainly, a more detailed description of the principles that activate the different gradients of kinship among the Kaingang would be quite opportune to clarify the reflection, but I am content - and I hope the reader is as well - to indicate that aspects of coexistence - "respect," "shame" (my'a), solidarity, sharing - are central to understanding the location of the condition of becoming "relative." Thus, as in the Amazonian world, "it is precisely when they build 
their bodies of relatives that the indigenous collectives become local, that is, current, giving meaning to their own concepts of affinity and consanguinity (idem, p.418, emphasis in the original).

Relating the dynamics of politics and kinship observed in the context of the Sêgu land claim, I sought to reveal how the social, political and spatial configuration that the groups present contemporaneously are coherent with the model of factionalism that has been described for quite some time. In addition, it draws attention to the way that kinship relations can be questioned when political interests permeate the actions of individuals and/or indigenous collectives.

\section{Bibliography:}

ALMEIDA, Lédson Kurtz de. 2004. Análise Antropológica das Igrejas Cristãs entre os Kaingang Baseada na Etnografia, na Cosmologia e Dualismo. Tese de Doutorado, PPGAS/UFSC.

CARSTEN, Janet. 2004. After Kinship. Cambridge, Cambridge University Press.

CREPÈAU, Robert. 2002. "A Prática do Xamanismo entre os Kaingang do Brasil Meridional: uma breve comparação com o Xamanismo Bororo". In: Horizontes Antropológicos, Porto Alegre, ano 8, $\mathrm{n}^{\circ} 18$, pp.113-129.

FERNANDES, Ricardo Cid. 2003. Política e Parentesco entre os Kaingang: uma análise etnológica. Tese de Doutorado, PPGAS/ USP.

ROCHA, Cinthia Creatini da. 2005 Adoecer e Curar - Processos da Sociabilidade Kaingang. Dissertação de Mestrado, PPGAS/ UFSC.

SCHNEIDER, David M. 1984. A critique of the Study of Kinship. The University of Michigan Press.

SILVA, Sergio Baptista da, et al. 2008. "Coletivos indígenas em Porto Alegree regiões limítrofes”. In: I. Gehlen; M. B. Silva; S. R. Santos. (orgs.). Diversidade e Proteção Social: estudos quanti-qualitativos das populações de Porto Alegre. Porto Alegre, Century.

SouzA, Marcela Coelho de. 2004. "Parentes de sangue: Incesto, Substânciae Relação no Pensamento Timbira”. MANA 10(1): 25-60.

STRATHERN, Marilyn. 1992. After nature: English kinship in the late twentieth century. Cambridge, Cambridge University Press.

STRATHERN, Marilyn. 2005. Kinship, Law and the unexpected: Relatives are 
always a surprise. Cambridge, Cambridge University Press.

TOMMASINO, Kimiye. 2000 "Território e territorialidade Kaingang.

Resistência cultural e historicidade de um grupo Jê”. In: L. T. Mota; F. S. Noelli;

K. Tommasino (orgs.) Urí e Wãxi - Estudos Interdisciplinares dos Kaingang. Londrina: Ed.UEL.

VEIGA, Juracilda. 1994 Organização Social e Cosmovisão Kaingang: uma introdução ao parentesco, casamento e nominação em uma sociedade Jê Meridional. Dissertação de Mestrado, Campinas, IFCH-UNICAMP.

VEIGA, Juracilda. 2000 Cosmologia e práticas rituais Kaingang. Tese de Doutorado. Departamento de Antropologia e Instituto de Filosofia e Ciências Humanas da Universidade Estadual de Campinas, SP. VIVEIROS DE CASTRO, Eduardo. 2002. "Atualização e contra-efetuação do virtual na socialidade amazônica: o processo de parentesco". In: A inconstância da alma selvagem. Cosac \& Naify.

\section{About the author}

Doctoral candidate in the Graduate Program in Social Anthropology at the Federal Universiity at Santa Catarina.

\section{Publications:}

ROCHA , C. C. "Caracterização Histórica e Sociocultural da Terra Indígena Iraí (RS)" In: História Geral do Rio Grande do Sul - Povos Indígenas. Editora Passo Fundo: Livraria e Editora Méritos, 2009, v.5, p. 121-132. ROCHA, C. C.; GERBER, R. M. Boletim Avaliação da metodologia utilizada com povos indígenas pelo Projeto Microbacias 2. Boletim. , 2009.

\section{Contact Information}

Rua Nascente do Rio Vermelho, 845. CEP: 8806o-329. Florianópolis/ SC. E-mail: creatini@hotmail.com

Received 29/03/2011, approved 08/11/2011 